\title{
Genetic Variability Studies among Various Morphological and Quality Traits in Bathua (Chenopodium album L.)
}

\author{
Basavaraj, C.N. Hanchinamani, S.J. Imamsaheb*, H.P. Hadimani and \\ S.H. Ramanagouda \\ Department of Vegetable Science, K. R. C. College of Horticulture, Arabhavi - 591218 , \\ Karnataka, India \\ *Corresponding author
}

\section{A B S T R A C T}

\section{Keywords}

Bathua (Chenopodium album L.), Phenotypic coefficient

Article Info

Accepted:

22 July 2018

Available Online:

10 August 2018
Studies on genetic variability, heritability and genetic advance were carried out with 24 genotypes of Bathua (Chenopodium album L.) in Department of Vegetable Science, College of Horticulture, Arabhavi. Considerable amount of genotypic and phenotypic coefficient of variation was observed for all characters studied. Phenotypic variation was greater than that of the genotypic variations for all the characters. The greater portion of total phenotypic variation was due to the genotypic variation. Highest genotypic and phenotypic coefficient of variation was observed for foliage yield per plant (40.58 and 42.73, respectively). Heritability values were higher for Foliage yield per plant (90.16), Calcium (89.10\%), Protein (85.82\%), Inflorescence length (85.50), Leaf area (84.83\%), Vitamin- A $(85.48 \%)$, Fresh weight of plant $(70.10)$, indicating the better potentials of improving these characters for improvement of yield. Maximum genetic advance expressed as percentage of mean was recorded for foliage yield per plant.

\section{Introduction}

Bathua (Chenopodium album L.) a crop of European origin, has recently gained worldwide attention due to its nutritional value. Economically leaves and stem are used as vegetable, either raw or cooked like spinach, tender leaves are used in many Indian dishes like Bathua Roti, Bathua Paratha, Stuffed breads, they are popular in Punjab. In the Himalayan region as an important subsidiary grain crop, as a potherb, for secondary fodder and salad dressings (Bhargava et al., 2007). This is nutritional rich in vitamin-A (11,300 IU), Vitamin-C (35mg) and also having medicinal values like laxative property and act as blood purifier (Sanwal, 2008). The variability in the genotypes is very important for any genetic improvement programme. Again for improving the efficiency of selection in any base population the presence of genetic variability is of prime importance. However, since most of the economically important plant characters are polygenic in nature and are highly influenced by environment, it becomes to conclude whether the desired variability is heritable or is due to environmental factors. Heritability and genetic advance estimates for different yield contributing traits help the breeder to 
apply appropriate breeding methodology in the crop improvement programme.

\section{Materials and Methods}

The experiment was conducted at the Department of Vegetable Science, KRCCH, Arabhavi, University of Horticultural Sciences, Bagalkot and carried out during kharif 2017 using 24 bathua genotypes viz., EC-359444, NC-50229, HUB-1, HUB-2, EC359445, IC-243192, HUB - 3, IC-341703, HUB - 4, IC-109249, NIC-22506, HUB - 5, NC-58616, NIC-22492, IC-109235, HUB-6, HUB - 8, IC-415477, IC-540831, NIC-22517, HUB - 7, IC-540842, IC-4152393, HUB - 9 were evaluated in Randamized block design with 3 replications.

The sowing was done on ridge with spacing of $30 \mathrm{~cm} \mathrm{X} 20 \mathrm{~cm}$. Observations for different traits viz., Plant height at $(\mathrm{cm})$, Plant spread $\mathrm{N}-\mathrm{S}(\mathrm{cm})$, Plant spread E-W (cm), Leaf area $\left(\mathrm{cm}^{2}\right)$, Stem girth $(\mathrm{cm})$, Number of days to first flowering, Number of inflorescence per plant, Inflorescence length $(\mathrm{cm})$, Number of leaves per plant, Fresh weight of plant $(\mathrm{g})$, Foliage yield per plant (g), Foliage yield per plot $(\mathrm{kg})$, Foliage yield per hectare (tonnes), Vitamin- A (mg), Vitamin -C (mg), Protein (g), Calcium (mg) were recorded on randomly selected 5 plants in each replication were recorded from 5 randomly selected competitive plants for each genotype. Analysis of variance was done for partitioning the total variation into variation due to treatments and replication according to procedure given by Panse and Sukharme (1967).

\section{Results and Discussion}

Genetic variability, heritability and genetic advance

The genetic parameters viz. mean, range, genotypic variances, phenotypic variances, phenotypic coefficient of variation (PCV) and genotypic coefficient of variation (GCV), heritability estimates and predicted genetic advance as percent of mean for characters studied are presented in Table 1 and 2.

In the present study, phenotypic coefficient of variation in general were higher than genotypic coefficient of variation for all the traits, but the difference was very low, indicating low environmental effect on the expression of all the traits and is suggestive of the heritable nature of the traits. These results were similar with the findings of Bhargava et al., (2007).

The estimates of various genetic parameters are given in Table 1 and 2. High GCV and PCV were observed for Leaf area, number of inflorescence per plant, fresh weight of plant, foliage yield per plant, foliage yield per plot, foliage yield per hectare, indicating the higher magnitude of variability for these traits and consequently more scope for their improvement through selection. The similar results were also observed by Meena et al., (2014).

Moderate GCV and PCV were observed for inflorescence length, plant height, number of leaves per plant, inflorescence dry weight, vitamin -A content, protein, and calcium content of leaves.

This implied equal importance of additive and non-additive gene action in these characters. These results are in accordance with results of Panda (2017) for number of leaves per plant; Diwan (2015) for inflorescence length, calcium content; Selvin et al., (2013) for protein content; Bhargava et al., (2007) for vitamin - A content.

Low GCV and PCV were observed for days to first flowering, plant spread E-W, plant spread $\mathrm{N}-\mathrm{S}$, stem girth, vitamin- $\mathrm{C}$ content of leaves. 
Table.1 Estimates of mean, range, components of variance, heritability, genetic advance and genetic advance over percent of mean for growth, flowering and earliness parameters in bathua

\begin{tabular}{|c|c|c|c|c|c|c|c|c|c|c|}
\hline Sl. No. & Character & Mean \pm S. Em & Range & GV & $\mathbf{P V}$ & GCV $(\%)$ & PCV $(\%)$ & $\mathrm{h}^{2}$ & GA & GAM \\
\hline \multicolumn{11}{|c|}{ Growth and flowering parameters } \\
\hline 1. & Plant height at $(\mathrm{cm})$ & $56.40 \pm 6.18$ & $31.93-75.89$ & 77.84 & 192.56 & 15.64 & 24.60 & 40.42 & 11.55 & 20.48 \\
\hline 2. & Plant spread N-S (cm) & $24.72 \pm 1.46$ & $19.65-29.26$ & 3.14 & 9.58 & 7.17 & 12.51 & 32.82 & 2.09 & 8.46 \\
\hline 3. & Plant spread E-W (cm) & $24.22 \pm 2.18$ & $19.16-28.73$ & 0.93 & 15.20 & 3.99 & 16.09 & 6.15 & 0.49 & 2.03 \\
\hline 4. & Leaf area $\left(\mathrm{cm}^{2}\right)$ & $57.95 \pm 2.96$ & $39.92-76.04$ & 147.53 & 173.92 & 20.95 & 22.75 & 84.83 & 23.04 & 39.76 \\
\hline 5. & Stem girth $(\mathrm{cm})$ & $2.18 \pm 0.20$ & $1.68-2.73$ & 0.02 & 0.15 & 6.64 & 17.77 & 13.97 & 0.11 & 5.11 \\
\hline 6. & Number of days to first flowering & $39.31 \pm 1.39$ & $33.97-42.86$ & 4.63 & 10.49 & 5.47 & 8.23 & 44.23 & 2.95 & 7.50 \\
\hline 7. & Number of inflorescence per plant & $10.54 \pm 1.46$ & $6.20-16.86$ & 4.98 & 11.43 & 21.18 & 32.07 & 43.63 & 3.03 & 28.82 \\
\hline 8. & Inflorescence length $(\mathrm{cm})$ & $17.13 \pm 0.64$ & $12.40-21.66$ & 7.38 & 8.63 & 15.86 & 17.15 & 85.50 & 5.17 & 30.21 \\
\hline
\end{tabular}

GCV-Genotypic co-efficient of variation GAM - Genetic advance as per cent of mean PCV-Phenotypic co-efficient of variation

Table.2 Estimates of mean, range, components of variance, heritability, genetic advance and genetic advance over percent of mean for yield and quality parameters in bathua

\begin{tabular}{|c|c|c|c|c|c|c|c|c|c|c|}
\hline Sl. No. & Character & Mean \pm S. Em & Range & GV & PV & $\begin{array}{c}\text { GCV } \\
(\%)\end{array}$ & $\begin{array}{c}\text { PCV } \\
(\%)\end{array}$ & $h^{2}$ & GA & GAM \\
\hline A. & \multicolumn{10}{|l|}{ Yield and quality parameters } \\
\hline 1 & Number of leaves per plant & $91.01 \pm 10.49$ & $47.33-124.33$ & 176.24 & 506.49 & 14.58 & 24.72 & 34.80 & 16.13 & 17.72 \\
\hline 2 & Fresh weight of plant (g) & $116.11 \pm 13.09$ & $49.67-205.83$ & 1205.78 & 1720.04 & 29.90 & 35.71 & 70.10 & 59.89 & 51.58 \\
\hline 3 & Foliage yield per plant (g) & $62.99 \pm 4.87$ & $33.60-144.66$ & 653.60 & 724.94 & 40.58 & 42.73 & 90.16 & 50.00 & 79.37 \\
\hline 4 & Foliage yield per plot (kg) & $1.34 \pm 0.18$ & $0.84-2.45$ & 0.09 & 0.19 & 23.00 & 33.01 & 48.57 & 0.44 & 33.03 \\
\hline 5 & $\begin{array}{l}\text { Foliage yield per hectare } \\
\text { (tonnes) }\end{array}$ & $8.96 \pm 1.20$ & $5.62-16.37$ & 4.33 & 8.69 & 23.21 & 32.87 & 49.83 & 3.02 & 33.75 \\
\hline 6 & Vitamin- A (mg) & $389.16 \pm 17.19$ & $248.83-523.73$ & 5223.91 & 6111.07 & 18.57 & 20.08 & 85.48 & 137.65 & 35.37 \\
\hline 7 & Vitamin $-\mathrm{C}(\mathrm{mg})$ & $43.07 \pm 1.11$ & $37.83-46.27$ & 3.53 & 7.24 & 4.36 & 6.24 & 48.80 & 2.70 & 6.28 \\
\hline 8 & Protein $(\mathrm{g})$ & $4.11 \pm 0.16$ & $2.84-6.04$ & 0.50 & 0.58 & 17.21 & 18.58 & 85.82 & 1.35 & 32.85 \\
\hline 9 & Calcium (mg) & $1202.19 \pm 42.51$ & $799.83-1599.83$ & 44343.78 & 49766.00 & 17.51 & 18.55 & 89.10 & 409.48 & 34.06 \\
\hline
\end{tabular}

GV-Genotypic variance $\quad \mathrm{h}^{2}$-Broad sense heritability PV-Phenotypic variance GA-Genetic advance

GCV-Genotypic co-efficient of variation GAM - Genetic advance as per cent of mean PCV-Phenotypic co-efficient of variation 
This indicates the narrow genetic base hence variability has to be generated in these traits either through introduction or hybridising divergent genotypes to recover transgressive segregants or by mutation breeding. These results are in conformity with the results of Fikreselassie et al., (2012) for days to first flowering; Diwan (2015) for stem girth.

The very high estimates of heritability coupled with high values of genetic advance over per cent mean were observed for traits such as leaf area, inflorescence length, fresh weight of plant, foliage yield per plant, vitamin-A, protein, calcium. These characters are under the influence of additive gene action. These results are in accordance with the findings of Panda et al., (2017) and Umakanta et al., (2014).

High heritability (>60\%) with low genetic advance $(0-10 \%)$ indicates the influence of non-additive gene action and considerable influence of environment on the expression of these traits. These traits could be exploited through manifestation of dominance and epistatic components through heterosis. Moderate to low heritability coupled with high GA indicates the importance of additive gene effect. Low to moderate heritability with high GAM was obtained for plant height, number of inflorescence per plant, foliage yield per plot, foliage yield per hectare. This indicates the importance of additive gene effects for these traits and there can be better response to selection. These results are in accordance with the findings of Yogendra et al., (2015) for plant height. Low heritability with low GA indicates that, the character is highly influenced by environmental effect and selection would be ineffective. Moderate to low heritability with moderate to low values of GAM were observed for the characters like plant spread E-W, plant spread N-S, number of leaves per plant, stem girth, days to first flowering, vitamin-C. Similar findings were also obtained Yogendra (2015) for number of leaves per plant and number of branches per plant.

Prevalence of high degree of additive components like high estimates of heritability coupled with high GAM and presence of high GCV and PCV for the traits like leaf area, inflorescence length, fresh weight of plant, foliage yield per plant, vitamin-A, protein, calcium, indicated additive gene action hence, higher degree of genetic improvement for these traits can be achieved through selection using the existing germplasm stock.

\section{References}

Bhargava, A., Shukla, S. and Ohri, D., 2007, Genetic variability and interrelationship among various morphological and quality traits in Quinoa (Chenopodium quinoa Willd.). Field Crops Res., 101: 104-116.

Diwan, I. S., 2015, Genetic studies in amaranthus (Amaranthus sp.) germplasm. M. Sc. Thesis, Indira Gandhi Krishi Vishwavidyalaya, Raipur.

Fikreselassle, M., Zeleke, H. and Alemayehu, N., 2012, Genetic variability of Ethiopian fenugreek (Trigonella foenum-graecum L.) landraces. J. plant Breed. Crop sci., 4 (3): 39-48.

Meena, Y. K., Jadhao, B. J. And Kale, V. S., 2014, Genetic analysis of agronomic traits in coriander. SABRAO J. Breed. Genet., 46 (2): 265-273.

Meena, Y. K., Kale, V. S. and Meena, O. P., 2014, Correlation coefficient and path analysis in coriander. International Journal of Scientific and Research Publication, 4 (6): 52-59.

Panda, R. K., Mishra, S. P., Nandi, A., Sarkar, S., Pradhan, K., Das, S., Patnaik, A. and Padhiary, A. K., 2017, Genetic variability and varietal performance in 
vegetable amaranthus (Amaranthus sp.). Journal of Pharmacognosy and Phytochemistry I, 6 (6): 1250-1256.

Sanwal, S. K., 2008, Underutilized vegetable and spice crops. Agrobios, Jodhpur, 231-235p.

Selvan, R. K., Yassin, M. G. and Govindarasu, R., 2013, Studies on genetic parameters in grain amaranthus (Amaranthus hypochondricus) as influenced by plant densities. J. Plant Breed. Genet., 1: 34-42. Umakanta, S., Tofazzal, I., Golam, R. And Shinya, O., 2014, Genotypic variability for nutrient, antioxidant, yield and yield contributing traits in vegetable amaranth. Journal of Food, Agriculture \& Environment., 12 (3\&4): 168-174.

\section{How to cite this article:}

Basavaraj, C.N. Hanchinamani, S.J. Imamsaheb, H.P. Hadimani and Ramanagouda, S.H. 2018. Genetic Variability Studies among Various Morphological and Quality Traits in Bathua (Chenopodium album L.). Int.J.Curr.Microbiol.App.Sci. 7(08): 4147-4151.

doi: https://doi.org/10.20546/ijcmas.2018.708.433 